\title{
IMPACT OF NATIONAL DEBT BURDEN ON ECONOMIC STABILITY IN NIGERIA
}

\author{
Kingsley Onyekachi ONYELE ${ }^{1}$, Emmanuel Chijioke NWADIKE $^{2}$ \\ ${ }^{1}$ Michael Okpara University of Agriculture, Umuahia, Abia State, Nigeria \\ ${ }^{2}$ Federal University of Technology, Owerri, Imo State, Nigeria \\ Corresponding author's e-mail: onyele.kingsley@mouau.edu.ng
}

\begin{abstract}
The study argues that national debt becomes a burden when debt overhang is rising, a foreign reserve is inadequate to cover short-term external debt and government revenue is inadequate for debt servicing. This paper investigates the impact of national debt burden on economic stability in Nigeria. Data spanning from 1981 to 2019 have been collated from the World Development Indicators and Central Bank of Nigeria Statistical Bulletin, 2019 edition. Consequently, the variables used to measure debt burden are total debtto-GDP ratio (debt overhang), short-term external debt-to-reserves ratio (reserve adequacy) and debt service cost-to-government revenue ratio (revenue adequacy) with exchange rate as a control variable, while economic stability is measured with real GDP growth rate. The Autoregressive Distributed Lag (ARDL) model is used for the analysis since the variables are stationary at both levels and first difference. The ARDL estimation shows that the explanatory variables collectively cause a diminishing impact on economic stability in the long run with revenue adequacy having a negative and significant impact. In the short run, all the components of debt burden, except debt overhang, have a negative and significant impact on economic stability. Under this circumstance, exchange rate has a positive and significant impact on economic stability in the long run.
\end{abstract}

Keywords: Autoregressive Distributed Lag (ARDL), debt burden, debt servicing, economic stability, exchange rate, Nigeria, reserves.

JEL Classification: E62, F31, G31, P24

\section{INTRODUCTION}

National debt is of macroeconomic importance as it helps provide investible funds, reduce budget constraint by making funds available to finance balance of payment and fiscal deficits. The World Bank (2020) emphasized that nations, especially resource-scarce economies, borrow to improve capital formation and investments, which are often deterred by the lack of domestic savings. The dualgap analysis shows that debt is often inevitable because foreign exchange earnings and savings necessary to finance domestic investments are not usually adequate, especially in developing countries. However, poor management of national debt could cause financial distress and economic crisis in the debtor country due to debt servicing. As such, Ogunlana (1995) opined that the right blend of domestic savings and debt was fundamental to attaining sustainable economic growth. 
The question is: At what point is national debt a burden? To answer this question, the Price Waterhouse Cooper (PWC) (2020); Csaba and Gabriella (2017) and Ogunlana (1995) state that rising debt overhang (total debt-to-GDP ratio), debt service-to-government revenue ratio, and short-term external debt-to-foreign reserves ratio over a long period are pointers to national debt burden and economic instability. If borrowed funds are not invested in economically viable projects, repayment of the principal sum and agreed interest becomes difficult. Like most unindustrialized nations, Nigeria has suffered from several economic upheavals arising from insufficient funds, collapse of local industries, frequent fiscal deficit, low exports, constant balance of payment deficit due to rising imports, etc. This situation has led to widening of savings-investments gap and accumulation of debt that requires a large proportion of government revenue and drawdown on foreign reserves to service (Onyele \& Nwokoacha, 2016a). A careful investigation of this phenomenon using annual time series data for Nigeria indicates that rising national debt over a long period triggers economic instability due to inadequate government revenue, foreign reserves and domestic income to cover the debt service cost.

In Nigeria, deficit financing has led to borrowings from richer countries, multinational finance institutions, such as the International Monetary Fund (IMF), the World Bank, African Development Bank (ADB) amongst others. Unfortunately, the rising national debt in Nigeria has begun to outweigh the country's revenue generation capacity and drawing down on foreign reserves, hence stifling the much-needed public capital investments and economic productivity. Also, it has been reported that these borrowed funds are often mismanaged and siphoned by public officers, hence, are not used for economically productive activities, leading to debt burden, capital flight and economic instability in the longrun (Iyatse, 2020; Onyele \& Nwokocha, 2016b). In fact, Nigeria has failed to prudently use borrowed funds over the years due to a high rate of embezzlement and sharp practices among public officers, prompting the comment of David Cameron (former British Prime Minister) describing Nigeria as "fantastically corrupt" during an anti-corruption summit in London. The level of debt burden has impeded domestic investments and production, resulting in various kinds of debt restructuring with some concessional borrowings, as well as foreign debt relief by Paris Club in 2005 (Ekperiware \& Oladeji, 2012). Ironically, fourteen years after the debt relief, Nigeria's debt profile is still rising with low economic growth and development.

This paper addresses a fundamental research question: What is the impact of debt burden on economic stability in Nigeria? To answer this question, the study measures debt burden by total debt-to-GDP ratio (debt overhang), short-term external debt-to-external reserves ratio (reserves adequacy) and debt service-torevenue ratio (revenue adequacy), which are scarcely posted in the literature. Hence, the study contributes to the literature by introducing new variables such as revenue and reserves adequacy into the model, while most prior studies focused on the amount of debt stock and debt service without considering the dynamics of revenue and reserve adequacy. This objective can be successfully achieved using a historical analysis of data tied to the aforementioned variables in an Autoregressive Distributed Lag (ARDL) model. The structure of this paper is as follows - after the 
introduction, the literature review is provided, which is followed by the methodological framework; data analysis and discussion of findings, and the summary and policy implication of the study.

\section{LITERATURE REVIEW}

\subsection{Conceptual Framework}

National debt also known as government debt, sovereign debt, public debt or deficit financing is the aggregate amount of money that government owes either to their citizens and/or local financial organisations (domestic debt) or foreign financial organisations (external debt). On the other hand, debt burden is the financial crisis or distress arising from debt repayment due to constant interest payment from government revenue and foreign reserves. The use of government revenue to finance interest payments on public debt directly hinders the disposable income and domestic savings in the indebted country (Balago, 2014). Similarly, Sachs (1989) indicated that in a situation where revenue mobilization was geared towards debt servicing; economic instability was likely to occur since it created much leakage in the domestic economy as displayed in Fig. 1.

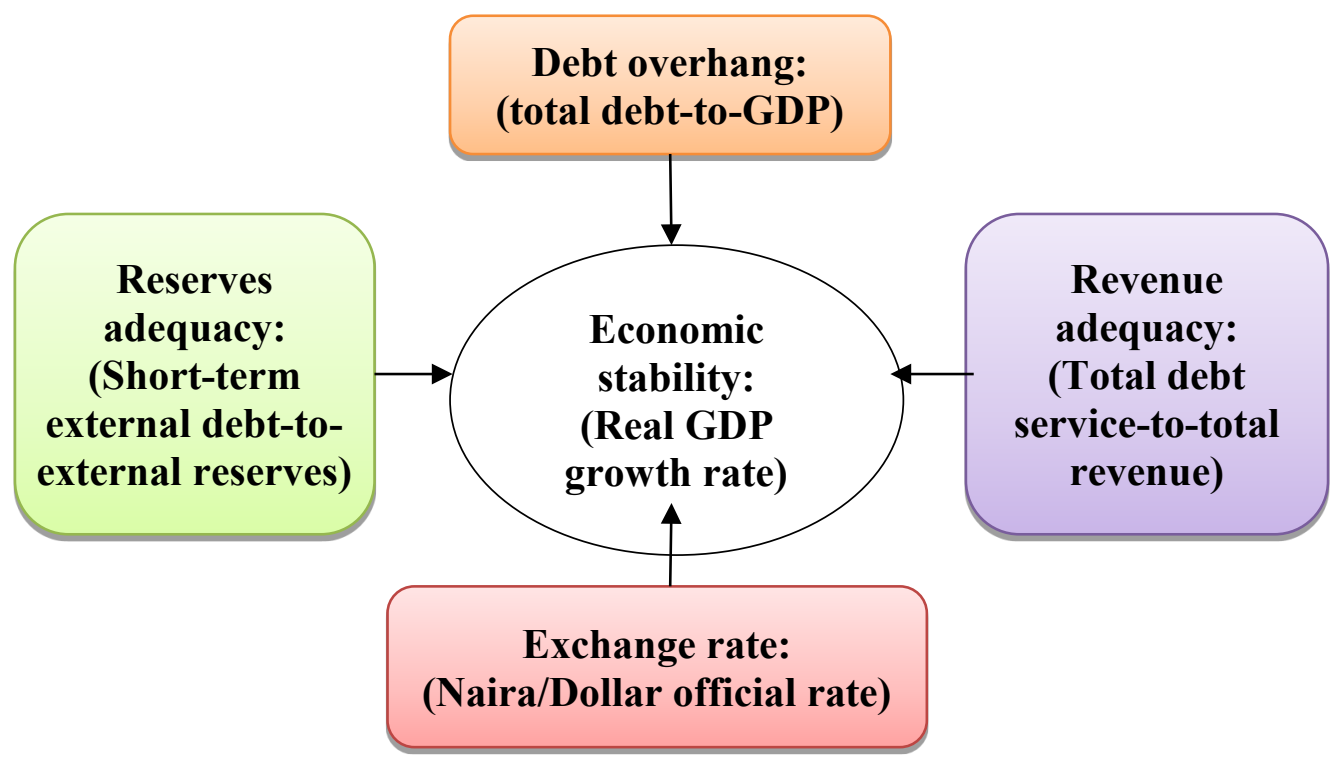

Fig. 1. Conceptual framework (Designed by the authors, 2021).

\subsubsection{Some Stylized Facts on National Debt in Nigeria}

Nigeria has experienced difficulty in debt servicing following a sudden decline in oil prices. With volatile oil prices leading to low revenue generation and low revenue generation leading to fiscal deficit, the Nigerian economy has been depending on debt from both external and internal sources. Hence, if national debt is not prudently managed in Nigeria, a vicious circle of debt burden and economic instability will persist as displayed in Fig. 2. 


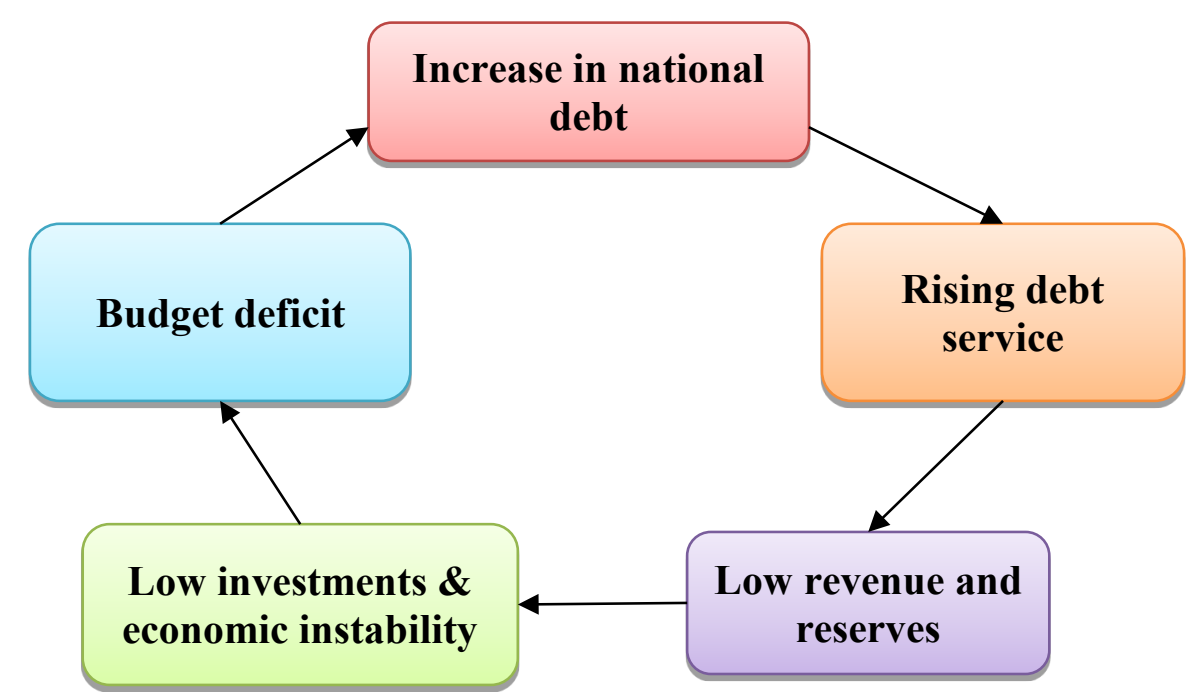

Fig. 2. Debt-economic instability relationship (Developed by the authors, 2021).

Nigeria has accumulated huge debt with rising cost of debt service which has undermined economic stability as domestic investments are being crowded out by rising cost of debt servicing (see Fig. 3). It then implies that constant debt servicing diverts investments from economically productive activities, since government revenue is used to cushion interest payments on borrowed funds, thus hindering budget implementation, creating further budget deficit and debt burden.

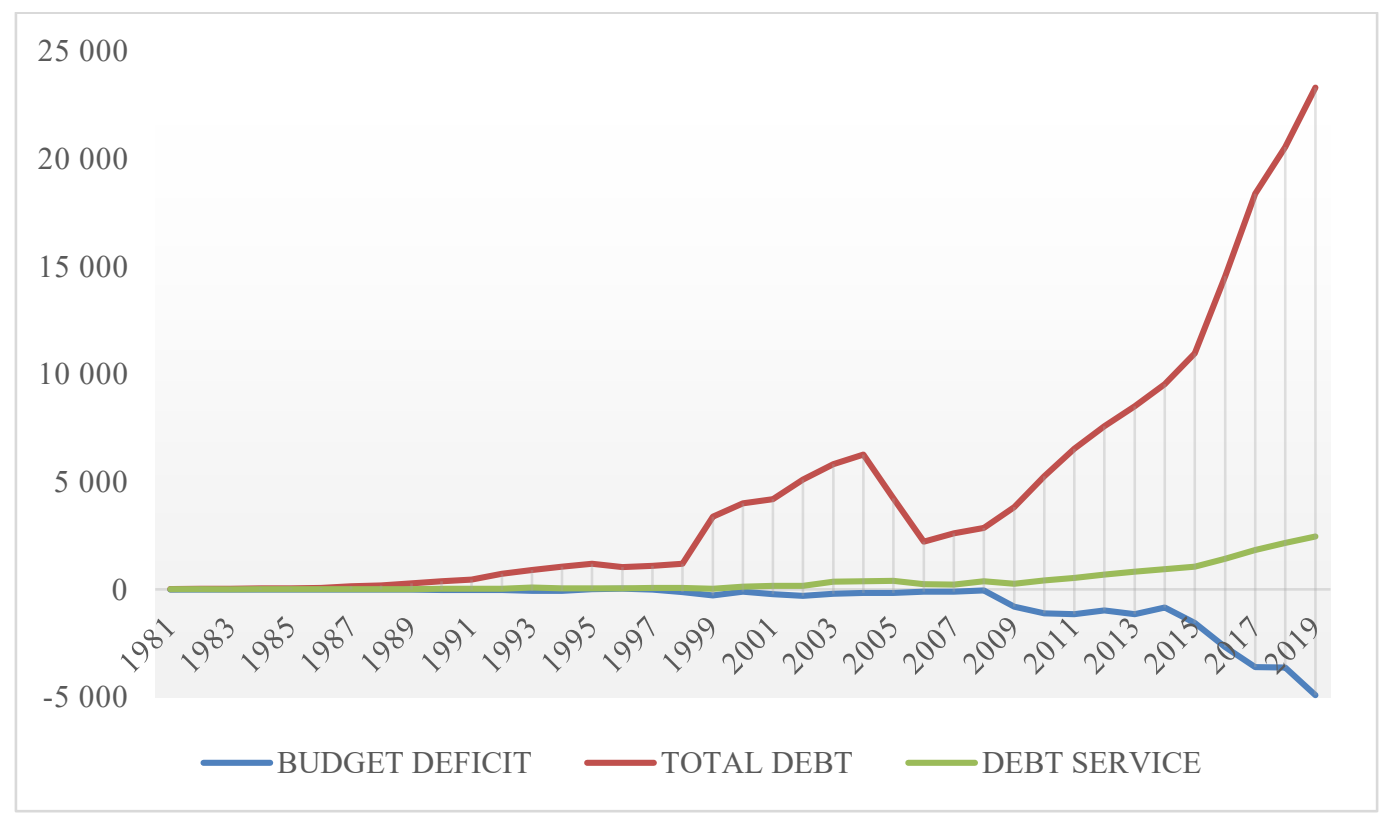

Fig. 3. Nigeria's debt profile (Central Bank of Nigeria Statistical Bulletin, 2019). 


\subsection{Theoretical Underpinning}

This study is majorly underpinned by the following theories.

\subsubsection{Debt Overhang Theory}

Debt overhang arises when debt stock exceeds government's ability to repay. This leads to an increase in taxes towards generating adequate revenue to settle both foreign and domestic creditors, thus discouraging investments due to a sudden increase in taxes. Thus, the indebted country retains only a fraction or nothing from domestic output and export revenue (Abdullahi et al., 2016). This implies that accumulation of debt hampers economic prosperity through tax disincentive. Tax disincentive denotes that rising debt stock impairs investments as potential investors foresee a possible tax increase on future income in a bid to repay the borrowed funds. As such, the debt overhang theory recommends that borrowed funds be well invested in productive sectors capable of generating adequate revenue for repaying the debt and financing domestic investments (Were, 2001).

\subsubsection{Crowding-Out Effect}

This postulates that economic stability is undermined by debt burden if debt service cost weighs down public expenditures (Zaheer et al., 2019). This implies that public investments are crowded-out as rising national debt obligations consume a large proportion of government revenue. By the crowding-out effect, a decrease in public investments transmits to a reduction in private investments due to the complementarily of some private and public investments. In as much as extreme national debt can result in liquidity constrain by crowding-out domestic investments in the debtor country; reliance on debt is a necessity for unindustrialized economies at their early stage of development since available financial resources at that phase could be inadequate to enhance the needed growth and development (Todaro \& Smith, 2006).

\subsubsection{Dependency Theory}

This theory states that advanced countries use debt agreements to impose progressive arrangements that are non-compatible with economic requirements and aspirations of less developed countries indebted to them (Ijirsar et al., 2016). The repercussion of overdependence on foreign creditors is that it creates an avenue through which developed countries exert control over less developed indebted countries by imposing the kind of projects, expertise, number of local and expatriate workers and decisions regarding pricing in the debtor country.

\subsection{Empirical Literature Review}

\subsubsection{Studies by Developed Countries}

The study by Gomez-Puig \& Sosvilla-Rivero (2015) explored the influence of public debt on economic performance in countries under the European Economic and Monetary Union (EMU) from 1960 to 2012. The ARDL bounds testing approach was applied for the data analysis. The findings revealed that public debt hindered long-run economic performance of EMU countries, whilst in some 
specific cases, its short-run effect was positive. In Greece, Dritsaki (2013) examined the linkages between economic growth, exports and government debt between 1960 and 2011. The investigation was done using the vector error correction model (VECM) and the Granger causality approach. Specifically, the results indicated a one-way causal flow exports to economic growth and economic growth to public debt. In the long run, there was a one-way causal flow from economic growth to government debt.

\subsubsection{Studies by Developing Countries}

A recent study by Saungweme \& Odhiambo (2020) ascertained the impact of national debt on economic growth from 1970 to 2017 in Zimbabwe. By applying the Autoregressive Distributed Lag (ARDL) for the data analysis, it was observed that economic growth was negatively affected by both domestic and external debt in the long and short run. The findings further showed that domestic debt hindered economic progress than external debt. Njoroge (2020) used the vector error correction model and ARDL methods to analyse archival data, which showed a positive long-run causality between public debt and real GDP growth in Kenya.

Zaheer et al. (2019) investigated the impact of government debt on credit to private sector in Pakistan, using monthly data from 1998:M6 to 2015:M12. It was found that a one percentage point growth in government debt borrowing crowded out of the private sector credit. Daka et al. (2017) assessed the impact of external borrowing on the Zambian economy from 1980 to 2014 using ARDL. The outcome of the analysis revealed that external borrowing was negatively related with economic growth in the long run, while this relationship was found to be positive in the short run. Also, debt servicing was found to exert a negative and significant influence on the Zambian economy.

Using time series data from 1974 to 2014, Saifuddin (2016) examined how economic growth was influenced by public debt. The technique used for the estimation was the two stage least squares (TSLS). The outcome of the TSLS indicated that a positive influence of public debt on investments triggered economic growth. Anning et al. (2016) investigated the impact of government debt on the economic growth of Ghana adopting the methodology of the simple Ordinary Least Squares (OLS) with data spanning from 1990 to 2015. The analysis showed an adverse economic effect of government debt in Ghana.

Hussain et al. (2015) estimated the linkages between government debts on economic growth of Sub-Saharan Africa from 1995 to 2012. The study applied panel OLS, which indicated that rising debt burden triggered negative trends in an economic growth rate. In a study of South Asian economies, Akram (2013) explored the nexus between public debt and economic growth of Bangladesh, India, Pakistan and Sri Lanka from 1975 to 2011 using panel data estimation techniques. The results showed that both external debt and the cost of debt servicing as well as domestic debt negatively affected economic growth and investments, which implied evidence of debt overhang effect and the crowding-out effect, respectively. 


\subsubsection{Nigerian Studies}

Didia \& Ayokunle (2020) disaggregated total public debt into external debt and domestic debt to investigate whether these two forms of debt had a varying impact on the economic growth in Nigeria. Utilising the Vector Error Correction Model (VECM) and data covering the period of 1980-2016, the study revealed that domestic debt had a statistically significant positive relationship with economic growth in the long run, while external debt exhibited a negative relationship with economic growth, which was not statistically significant. Udoh et al. (2020) used quarterly data from 2006 to 2018 to explore the influence of intergenerational debt burden on economic prosperity in Nigeria. The hypotheses were tested the ARDL model. It was found that debt overhang and debt burden in Nigeria were due to the usage of borrowed funds into unproductive activities such as payment of salaries and allowances, which had hindered economic growth.

Omodero (2019) emphasised the consequences of external loans in Nigeria between 1996 and 2018. Using the regression technique to analyse the data, it was revealed that external loans had a significant and negative impact on capital investment, while the cost of external debt exerted a positive and statistically significant impact on capital investment. Ochuko and Idowu (2019) investigated the effect of national debts on economic enhancement in Nigeria from 1981 to 2018. The estimation showed that external debt contributed less to the Nigerian economy, while domestic debt significantly enhanced economic growth. On the other hand, debt servicing cost had a negative and significant influence on economic growth.

Ezema et al. (2018) investigated the impact of external public debts on the economic growth in Nigeria, 1990-2016. The study made use of ordinary least squares regression model for short run and Johansson cointegration for long-run relationship. Result revealed that external debt positively and significantly affected economic growth of Nigeria but external debts services negatively and significantly affected economic growth in Nigeria. Oti et al. (2016) analysed nexus between Nigeria's debt burden and economic development for the period of 1980-2014. The Johansen test for cointegration corroborated that a long-run equilibrium relationship existed between economic development and debt stocks, and the Granger causality result showed that the various debt stocks granger caused the performance of the Nigerian economy.

Nwali \& Nkwede (2016) looked at the combined influence of internal and external debt burden on the Nigerian economy using data from 1961 to 2013. The technique of data analysis was based on the VECM. The results confirmed that both internal and external debt burden exerted a negative and statistically significant effect on economic growth in Nigeria. Egbetude (2012) investigated the causal linkages between economic growth and public debt using data spanning from 1970 to 2010. From the results obtained through the Vector Autoregressive (VAR) analysis, it was observed that a bi-directional causality existed between public debt and economic growth. 


\subsubsection{Summary of Empirical Review}

According to the empirical works evaluated, there is no common consensus in the literature due to divergence in economic structure, macroeconomic policies, methodological approach and time period covered. Also, none of the studies used ratios such as reserve adequacy and revenue adequacy as indicated by the various theories reviewed.

\section{METHODOLOGY}

\subsection{Sources and Description of Data}

This study employed annual secondary data between 1981 and 2019. These datasets were extracted from the World Development Indicators (WDI) and Central Bank of Nigeria (CBN) Statistical Bulletin. The measurement, description and sources of data are summarised in Table 1.

Table 1. Measurement, Description and Data Sources (Compiled by the authors)

\begin{tabular}{|c|c|c|c|}
\hline Variable & Measurement & Description & Source \\
\hline $\begin{array}{l}\text { Economic } \\
\text { stability }\end{array}$ & $\begin{array}{l}\text { Real GDP growth rate } \\
(R G D P G R)\end{array}$ & $\begin{array}{l}\text { Positive RGDP growth rate denotes } \\
\text { economic stability. }\end{array}$ & $\begin{array}{l}\text { CBN statistical } \\
\text { bulletin }\end{array}$ \\
\hline $\begin{array}{l}\text { Debt } \\
\text { overhang }\end{array}$ & $\begin{array}{l}\text { Total debt-to-nominal } \\
\text { GDP (TDBT_GDP) }\end{array}$ & $\begin{array}{l}\text { It measures the usage of debt to } \\
\text { enhance an income level through } \\
\text { production of goods and services. }\end{array}$ & $\begin{array}{l}\text { CBN statistical } \\
\text { bulletin }\end{array}$ \\
\hline $\begin{array}{l}\text { Reserve } \\
\text { adequacy }\end{array}$ & $\begin{array}{l}\text { Short-term external } \\
\text { debt-to-reserves } \\
\left(S T E D \_R S V\right)\end{array}$ & $\begin{array}{l}\text { This measures how far external } \\
\text { reserves can cover short-term external } \\
\text { debt. A ratio rising above } 30 \% \text { shows } \\
\text { serious debt burden (PWC, 2020). }\end{array}$ & WDI \\
\hline $\begin{array}{l}\text { Revenue } \\
\text { adequacy }\end{array}$ & $\begin{array}{l}\text { Debt service cost-to- } \\
\text { government revenue } \\
\text { ratio }\left(D B T S \_R E V\right)\end{array}$ & $\begin{array}{l}\text { This examines how sufficient } \\
\text { government revenue is in servicing its } \\
\text { debt. }\end{array}$ & $\begin{array}{l}\text { CBN statistical } \\
\text { bulletin }\end{array}$ \\
\hline $\begin{array}{l}\text { Exchange } \\
\text { rate }\end{array}$ & $\begin{array}{l}\text { Naira-to-Dollar } \\
\text { official rate }\left(E X \_R\right)\end{array}$ & $\begin{array}{l}\text { Fluctuations in the exchange rate } \\
\text { would drive the debt service cost } \\
\text { higher since they are mostly } \\
\text { denominated in US dollars. }\end{array}$ & $\begin{array}{l}\text { CBN statistical } \\
\text { bulletin }\end{array}$ \\
\hline
\end{tabular}

\subsection{Model Specification}

According to Cunningham (1993), economies with rising debt burden spend a significant proportion of their financial resources in servicing debt liabilities, thus negatively influencing decisions concerning employment of capital and labour in the production function as functionally expressed in Eq. (1):

$$
R G D P \_G R=f\left(T D B T \_G D P, S T E D \_R S V, D B T S \_R E V, E X \_R\right) \text {. }
$$

Note: $R G D P \_G R, T D B T \_G D P, S T E D \_R S V, D B T S \_R E V$ and $E X \_R$ have been explained in Table 1 above. 
The ARDL technique originated by Paseran et al. (2001) was used for the estimation. The ARDL bounds test that captures the cointegrating vectors is specified in Eq. (2) as follows:

$$
\begin{aligned}
& \Delta R G D P_{-} G R_{t}=\delta_{0}+\sum_{j=1}^{p}\left(\delta_{1 j} \Delta R G D P_{-} G R_{t-j}\right)+\sum_{j=0}^{p}\left(\delta_{2 j} \Delta T D B T_{-} G D P_{t-j}\right) \\
& +\sum_{j=0}^{p}\left(\delta_{3 j} \Delta S T E D_{-} R S V_{t-j}\right)+\sum_{j=1}^{p}\left(\delta_{4 j} \Delta D B T S_{-} R E V_{t-j}\right)+\sum_{j=1}^{p}\left(\delta_{5 j} \Delta E X_{-} R_{t-j}\right) \\
& +\beta_{1} T D B T_{-} G D P_{t-1}+\beta_{2} S T E D_{-} R S V_{t-1}+\beta_{3} D B T S_{-} R E V_{t-1}+\beta_{4} E X_{-} R_{t-1}+\varepsilon_{t}
\end{aligned}
$$

where parameters $\delta_{1 j}-\delta_{5 j}$ denote the short-run dynamics, while parameters $\beta_{1}-\beta_{4}$ denote the long-run relationships; $\varepsilon_{t}$ represents the error term; $j$ denotes the optimal lag length. The collective significance of the explanatory variables is determined by the significance of the Wald's $F$-statistic at $5 \%$ level.

The error correction model (ECM) is represented by Eq. (3) below:

$$
\begin{aligned}
& \Delta R G D P_{-} G R_{t}=\phi_{0}+\sum_{j=1}^{p}\left(\phi_{1 j} \Delta R G D P_{-} G R_{t-j}\right)+\sum_{j=0}^{p}\left(\phi_{2 j} \Delta T D B T_{-} G D P_{t-j}\right) \\
& +\sum_{j=0}^{p}\left(\phi_{3 j} \Delta S T E D_{-} R S V_{t-j}\right)+\sum_{j=1}^{p}\left(\phi_{4 j} \Delta D B T S_{-} R E V_{t-j}\right)+\sum_{j=1}^{p}\left(\phi_{5 j} \Delta E X_{-} R_{t-j}\right) \\
& +E C T_{t-1},
\end{aligned}
$$

where, $\phi$ is the short-run estimates. ECT is the speed of adjustment to long-run equilibrium after any short-run discrepancies.

The ARDL long-run equation is specified in Eq. (4) below:

$\beta_{1} T D B T_{-} G D P_{t-1}+\beta_{2} S T E D_{-} R S V_{t-1}+\beta_{3} D B T S_{-} R E V_{t-1}+\beta_{4} E X_{-} R_{t-1}+\mu_{t}$,

where $\beta_{1}-\beta_{4}$ are the long-run coefficients of the independent variables.

\section{DATA ANALYSIS AND DISCUSSION}

\subsection{Trend Plot of the Data}

Prior to the estimation, the trend of the annual time series data used for the study was plotted (see Fig. 4). 


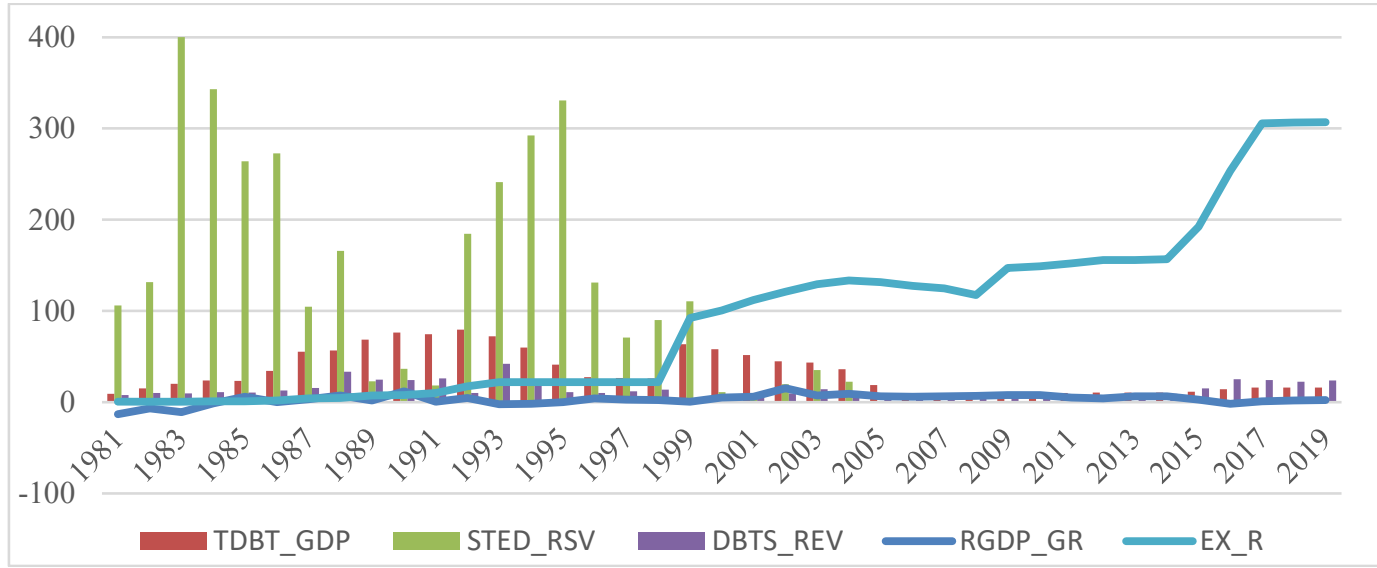

Fig. 4. Trend plot of data series used for the analysis (Central Bank of Nigeria, 2019; World Bank, n. d.).

Figure 4 indicates that annual $R G D P_{-} G R$ has been sluggish and largely downward trending, while debt burden has been rising. The unstable economic growth as reflected by $R G D P \_G R$ signals low domestic productivity, which would lower government revenue generation and further create finance gap that would necessitate more national debt in the future.

\subsection{Pre-Estimation Test}

The pre-estimation test is the unit root test based on Augmented Dickey-Fuller (ADF) and Phillips-Perron (PP) approaches (Dickey \& Fuller, 1979; Phillips \& Perron, 1988). As reported in Table 2 below, the test results indicate that the variables are integrated of both order zero, i.e., $I(0)$, and order one, i.e., $I(1)$. This is because the $p$-value of $R G D P \_G R$ is less than 0.05 at level, while the others are greater than 0.05 at level.

Table 2. Unit Root Test Results (The authors' computation, 2021)

\begin{tabular}{|c|c|c|c|c|c|}
\hline \multicolumn{6}{|l|}{ Panel A: ADF } \\
\hline \multirow{2}{*}{ Variables } & \multicolumn{2}{|c|}{ (a) Level; I(0) } & \multicolumn{2}{|c|}{ (a) First Difference; I(1) } & \multirow[t]{2}{*}{ Remark } \\
\hline & $t$-statistic & Prob. & $t$-statistic & Prob. & \\
\hline$R G D P G R$ & -3.982425 & 0.0179 & - & - & $I(0)$ \\
\hline TDBT_GDP & -2.700830 & 0.2421 & -4.332034 & 0.0077 & $I(1)$ \\
\hline STED_RESV & -3.535160 & 0.0502 & -6.239090 & 0.0000 & $I(1)$ \\
\hline DBTS REV & -2.957454 & 0.1571 & -5.868301 & 0.0001 & $I(1)$ \\
\hline$E X C H R$ & -2.082314 & 0.5383 & -4.469182 & 0.0054 & $I(1)$ \\
\hline \multicolumn{6}{|l|}{ Panel B: PP } \\
\hline \multirow{2}{*}{ Variables } & \multicolumn{2}{|c|}{ (a) Level; I(0) } & \multicolumn{2}{|c|}{ (a) First Difference; I(1) } & Remark \\
\hline & $t$-statistic & Prob. & $t$-statistic & Prob. & \\
\hline$R G D P \_G R$ & -3.982425 & 0.0179 & - & - & $I(0)$ \\
\hline$T D B T \_G D P$ & -2.399107 & 0.3741 & -4.332034 & 0.0077 & $I(1)$ \\
\hline STED RSV & -3.426613 & 0.0628 & -6.306091 & 0.0000 & $I(1)$ \\
\hline DBTS REV & -2.951429 & 0.1588 & -9.569026 & 0.0000 & $I(1)$ \\
\hline$E X R$ & -1.503414 & 0.8109 & -4.205285 & 0.0105 & $I(1)$ \\
\hline
\end{tabular}




\subsection{ARDL Estimation}

To investigate the long-run dynamics, the ARDL bounds test is conducted as displayed in Table 3.

Table 3. Bounds Test Results (The authors' computation, 2021)

\begin{tabular}{|l|l|l|l|l|}
\hline \multicolumn{5}{|c|}{$H_{0}:$ No relationships @ levels } \\
\hline $\boldsymbol{t}$-stat. & \multicolumn{1}{|c|}{ Value } & \multicolumn{1}{|c|}{ Significance } & $\boldsymbol{I}(\mathbf{0}) ;$ lower bound & $\boldsymbol{I}(\mathbf{1}) ;$ Upper bound \\
\hline$F$-stat. & 14.98350 & $10 \%$ & 1.90 & 3.01 \\
\hline$k$ & 4 & $5 \%$ & 2.26 & 3.48 \\
\hline & & $2.5 \%$ & 2.62 & 3.90 \\
\hline & & $1 \%$ & 3.07 & 4.44 \\
\hline
\end{tabular}

From the bounds test results, the $F$-statistic (14.983 50) exceeds the critical values of $I(0)$ and $I(1)$ at all levels of statistical significance, depicting evidence of a long-run relationship in the model. This shows that indicators of debt burden and economic stability have a long-run co-integrating relationship. The long-run coefficients are displayed in Table 4 below.

Table 4. Long-Run Estimates (The authors' computation, 2021)

\begin{tabular}{|l|l|l|l|l|}
\hline \multicolumn{1}{|c|}{ Variable } & \multicolumn{1}{|c|}{$\begin{array}{c}\text { Estimated } \\
\text { coefficients }\end{array}$} & \multicolumn{1}{c|}{$\begin{array}{c}\text { Standard } \\
\text { Error }\end{array}$} & \multicolumn{1}{c|}{$\begin{array}{c}\text { Test } \\
\text { statistic }\end{array}$} & Probability \\
\hline$T D B T \_G D P$ & 0.181022 & 0.022879 & 7.912319 & 0.0000 \\
\hline$S T E D[R S V$ & 0.000420 & 0.004973 & 0.084482 & 0.9334 \\
\hline$D B T S[R E V$ & -0.393928 & 0.080771 & -4.877118 & 0.0001 \\
\hline$E X \_R$ & 0.051519 & 0.005776 & 8.919573 & 0.0000 \\
\hline
\end{tabular}

The long-run estimates show that TDBT_GDP and DBTS_REV are significant parameters of national debt burden in Nigeria. The coefficients indicate that an increase in $T D B T_{-} G D P$ had a corresponding increasing impact on $R G D P P_{-} G R$ while $D B T S \_R E V$ had a diminishing impact on $R G D P \_G R$. This implies that shortage of revenue due to external debt servicing is a prominent source of debt burden in the long run, indicating that rising national debt and its service cost has robbed Nigeria of the necessary financial resources required to stabilise the economy. Equation (5) shows that $R G D P$ GR reduced by approximately $0.160967(16 \%)$ in the long run due to the combined effect of TDBT GDP, STED_GDP, DBTS_REV and EX_R. This shows a possibility of debt overhang and/or crowding-out effect of national debt in the long run.

$$
\begin{aligned}
& R G D P_{-} G R(-0.160967)=T D B T_{-} G D P(0.181022)+S T E D_{-} R S V(0.000420) \\
& -D B T S_{-} R E V(0.393928)+E X_{-} R(0.051519)
\end{aligned}
$$

The focus of the ECM is to study the speed of adjustment between the long run and short run. The estimated short-run parameters are also captured within the ECM framework as presented in Table 5. 
Table 5. ECM (The authors' computation, 2021)

\begin{tabular}{|c|c|c|c|c|}
\hline Variable & $\begin{array}{c}\text { Estimated } \\
\text { coefficients }\end{array}$ & $\begin{array}{c}\text { Standard } \\
\text { Error }\end{array}$ & $\begin{array}{c}\text { Test } \\
\text { Statistic }\end{array}$ & Probability \\
\hline$D\left(R G D P \_G R\right)$ & -0.380717 & 0.141095 & -2.698298 & 0.0135 \\
\hline$D(T D B T$ GDP $)$ & 0.078430 & 0.050591 & 1.550265 & 0.1353 \\
\hline$\overline{D(S T E D} R S V)$ & -0.016662 & 0.006985 & -2.385564 & 0.0261 \\
\hline$D(D B T S R E V)$ & -0.120655 & 0.055027 & -2.192652 & 0.0392 \\
\hline$D(E X R)$ & -0.045829 & 0.026949 & -1.700592 & 0.1031 \\
\hline $\mathrm{ECT}(-1)^{*}$ & -0.660636 & 0.113358 & -5.827882 & 0.0000 \\
\hline$R$-sq. $\left(R^{2}\right)$ & 0.804733 & \multicolumn{2}{|c|}{ Mean dependent variable } & 0.364722 \\
\hline Adj. $R$-sq. $\left(R^{2}\right)$ & 0.737141 & \multicolumn{2}{|c|}{ Std. Dev. dependent variable } & 4.745550 \\
\hline $\begin{array}{l}\text { Standard Error of } \\
\text { regression }\end{array}$ & 2.433032 & \multicolumn{2}{|l|}{ AIC } & 4.846286 \\
\hline Sum squared residuals & 153.9107 & \multicolumn{2}{|l|}{$\mathrm{SC}$} & 5.286153 \\
\hline Log likelihood & -77.23316 & \multirow{2}{*}{\multicolumn{2}{|c|}{$\mathrm{HQ}$}} & 4.999812 \\
\hline DW statistics & 1.920010 & & & \\
\hline
\end{tabular}

Note: * denote presence of long run equilibrium in the system.

The ECT is in consonance with a priori expectation since its coefficient is negative $(-0.660636)$ and statistically significant at $1 \%$ level. It then indicates yearly convergence to equilibrium in the long term after every shock or discrepancies in the short run such that approximately $66 \%$ of short-run shock/disequilibrium/discrepancies is corrected annually. The outcome of the ECT further lends credence to a long-run relationship between components of national debt burden and the measure of economic stability. The first differenced coefficients reveal that deviations in the long run occurred due to shocks associated with $S T E D \_R S V, D B T S \_R E V$ and $E X \_R$ in the short run as their respective coefficients were negative and significant.

The diagnostic and stability tests of the ARDL estimation are summarised in Table 6 .

Table 6. Diagnostic Tests (The authors' computation, 2021)

\begin{tabular}{|l|c|c|c|}
\hline \multicolumn{5}{|c|}{ Test for Serial Correlation } \\
\hline$F$-stat. & 0.585554 & Probability & 0.5661 \\
\hline \multicolumn{5}{|c|}{ Heteroskedasticity Test } \\
\hline$F$-stat. & 1.496748 & Probability & 0.1961 \\
\hline \multicolumn{5}{|c|}{ Jarque-Bera } \\
\hline$t$-stat. & 1.266379 & Probability & 0.530896 \\
\hline
\end{tabular}

$p>0.05$ implies absence of serial correlation and heteroskedasticity in the residuals, and the residuals are normally distributed.

The results demonstrate that the ARDL model passed the diagnostic tests. Also, the plots of cumulative sum (CUSUM) and cumulative sum of squares (CUSUMSQ) presented in Figs. 5 and 6 are within the acceptable boundaries, proving the stability of the ARDL estimation. 


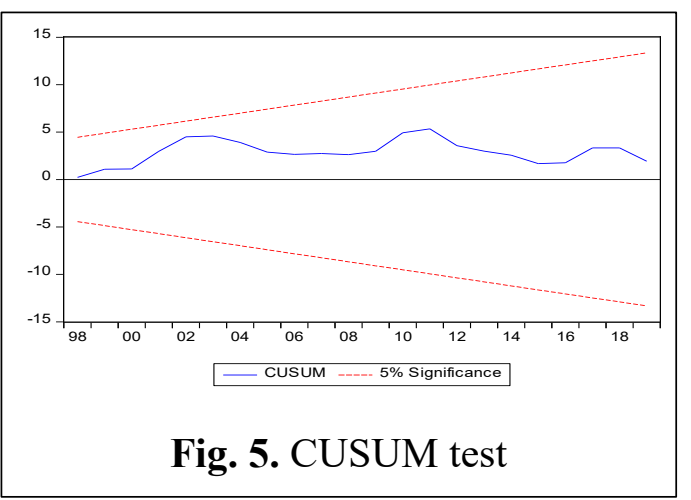

Fig. 5. Cumulative sum.

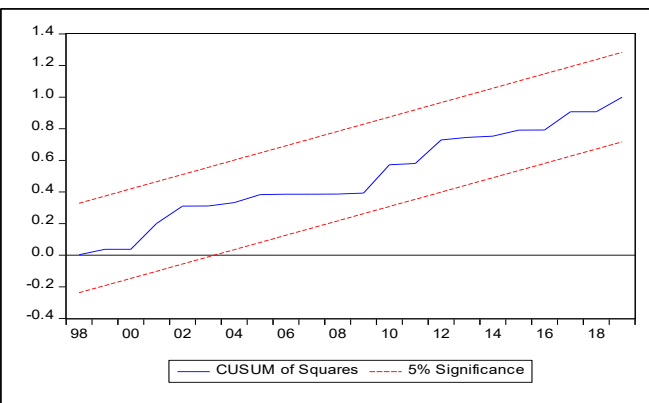

Fig. 6. CUSUMSQ test

Fig. 6. Cumulative sum of squares.

\section{CONCLUSION}

This paper considered the impact of debt burden on economic stability in Nigeria. A preliminary trend analysis revealed that Nigeria had been borrowing beyond its capacity to repay. Results from the Autoregressive Distributed Lag estimation revealed that debt burden, exchange rate and economic stability were tied by a long-run relationship. The long-run estimation showed that economic stability was collectively undermined by indicators of debt burden. In the short run, reserve adequacy, revenue adequacy and exchange rate had adverse and significant impact on real GDP growth rate. Thus, it was concluded that excessive borrowing had deprived Nigeria of the revenue and reserves required to fund domestic investments and enhance economic stability. It can be inferred from this study that national debt burden has a negative impact on economic stability in consonance with the debt overhang, crowding-out effects and dependency theories. Thus, policymakers should ensure that public debt is used to finance high income generating investments capable of attracting adequate revenue required to amortize the debt and also create future streams of revenue that would help reduce national debt and enhance future economic growth.

\section{ACKNOWLEDGEMENTS}

We express our profound gratitude to the editors and reviewers for their unbiased contribution towards improving the quality of this paper. Also, we are grateful to the various researchers whose studies were found helpful in the course of writing this paper.

\section{REFERENCES}

Abdullahi, M. M., Bakar, N. A., \& Hassan, S. B. (2016). Debt Overhang versus Crowding-Out Effects: Understanding the Impact of External Debts on Capital Formation in Theory. International Journal of Economics and Financial Issues, 6(1), 271-278.

Akram, N. (2013). Empirical Examination of Debt and Growth Nexus in South Asian Countries. Asia-Pacific Development Journal, 20(2), 29-52. https://doi.org/10.18356/0cbbc6e3-en 
Anning, L., Ofori, C. F., \&Affum, E. K. (2016). The Impact of Government Debt on the Economic Growth of Ghana: A Time Series Analysis from 1990-2015. International Journal of Innovation and Economic Development, 2(5), 31-39. https://doi.org/10.18775/ijied.1849-75517020.2015.25.2004

Balago, G. S. (2014). An Empirical Analysis of the Relationship between Government External Borrowings and Economic Growth in Nigeria. International Journal of Finance and Accounting, 3(4), 235-243. https://doi.org/10.5923/j.ijfa.20140304.03

Central Bank of Nigeria. (2019). Central Bank of Nigeria Statistical Bulletin, 30, 1981-2019 [statistics]. Retrieved from https://www.cbn.gov.ng/documents/statbulletin.asp

Csaba, C., \& Gabriella, C. (2017). Indicators Used for the Assessment of the Reserve Adequacy of Emerging and Developing Countries - International Trends in the Mirror of Theories. Financial and Economic Review, Central Bank of Hungary, 16(1), 5-45.

Cunningham, R. T. (1993). The Effects of Debt Burden on Economic Growth in Highly Indebted Nations. Journal of Economic Development, 18(1), 115-126.

Daka, L., Kapena, S., Fandamu, H., \& Phiri, C. (2017). The Impact of External Debt on Zambia's Economic Growth: AnARDL Approach. Journal of Economics and Sustainable Development, $8(8), 55-68$.

Dickey, D. A., \& Fuller, W. A. (1979). Distribution of Estimators for Autoregressive Time Series with a Unit Root. Journal of the American Statistical Association, 74(366), 427-431. https://doi.org/10.2307/2286348

Didia, D., \& Ayokunle, P. (2020). External Debt, Domestic Debt and Economic Growth in Nigeria. Advances in Economics and Business, 8(2), 85-94. https://doi.org/10.13189/aeb.2020.080202

Dritsaki, C. (2013). Causal Nexus between Economic Growth, Exports and Government Debt: The Case of Greece. International Conference on Applied Economics (ICOAE) Procedia Economics and Finance, 5, 251 - 259. https://doi.org/10.1016/S2212-5671(13)00031-2

Egbetunde, T. (2012). Public Debt and Economic Growth in Nigeria: Evidence from Granger Causality. American Journal of Economics, 2(6), 101-106. https://doi.org/10.5923/j.economics.20120206.02

Ekperiware, M. C., \& Oladeji, S. I. (2012). External Debt Relief and Economic Growth in Nigeria. American Journal of Economics, 2(7), 195-205. https://doi.org/10.5923/j.economics.20120207.05

Ezema, C. A., Nwekwo, N. M., \& Agbaji, B. C. (2018). Impact of External Debt and Its Services Burden to Economic Growth in Africa: Econometric Evidence from Nigeria. International Journal of Academic Research in Economics and Management Sciences, 7(3), 232-250. https://doi.org/10.6007/IJAREMS/v7-i3/4643

Gomez-Puig, M., \& Sosvilla-Rivero, S. (2015). Short-Run and Long-Run Effects of Public Debt on Economic Performance: Evidence from EMU Countries (RIAE Working Paper 1/37). Research Institute of Applied Economics. https://doi.org/10.2139/ssrn.2660117

Hussain, E., Haque, M., \& Igwike, R. S. (2015). Relationship between Economic Growth and Debt: An Empirical Analysis for Sub-Saharan Africa. Journal of Economics and Political Economy, 2(2), 262-275.

Ijirshar, V. U., Joseph, F., \& Godoo, M. (2016). The Relationship between External Debt and Economic Growth in Nigeria. International Journal of Economics and Management Sciences, 6(1), 1-5. https://doi.org/10.4172/2162-6359.1000390

Iyatse, G. (2020). Nigeria’s Debt Profile Hits $\$ 31$ Trillion. Retrieved January 10, 2020, from https://guardian.ng/news/nigerias-debt-profile-hits-n31-trillion/

Njoroge, L.W.N. (2020). Impact of Kenya's Public Debt on Economic Stability. Walden Dissertations and Doctoral Studies, 8963. Retrieved from https://scholarworks.waldenu.edu/dissertations/8963

Nwali, A., \& Nwede, F. (2016). Aggregate Public Debt Burden and Growth of a Fragile Economy: The Nigerian Experience. IOSR Journal of Economics and Finance, 7(2), 46-57. https://doi.org/10.9790/5933-0702024657

Ochuko, A. S., \& Idowu, E. (2019). Effect of Public Debt on Economic Growth in Nigeria: An Empirical Analysis. International Journal of Business and Economic Development, 7(2), 10-17. 
Ogunlana, O. A. (1995). Nigeria and the Burden of External Debt: The Need for Debt Relief. Central Bank of Nigeria (CBN). Retrieved September 4, 2016, from https:/g24.org/wpcontent/uploads/2016/01/Session-1_5-6.pdf

Omodero, C. O. (2019). External Debt Financing and Public Capital Investment in Nigeria: A Critical Evaluation. Economics and Business, 33, 111-126. https://doi.org/10.2478/eb-2019$\underline{0008}$

Onyele, K. O., \& Nwokoacha, E. B. (2016a). Sources of Public Funds and Economic Prosperity: The Nigerian Case. Journal of Business and Financial Affairs, 5(4), 1-8. https://doi.org/10.4172/2167-0234.1000215

Onyele, K. O., \& Nwokocha, E. B. (2016b). Influence of Capital Flight on Budget Implementation in Nigeria. Scientific Papers Series Management, Economic Engineering in Agriculture and Rural Development, 16(4), 247-256.

Oti, P. A., Odigbo, B. E., \& Odey, F. I. (2016). Nigeria's Debt Burden and Development Tangle: The Socio-Economic and Political Implications. Journal of Economics and Sustainable Development, 7(20), 92-101.

Pesaran, M., Shin, Y., \& Smith, R. (2001). Bounds Testing Approaches to the Analysis of Level Relationships. Journal of Applied Econometrics, 16(3), 289-326. https://doi.org/10.1002/jae.616

Price Waterhouse Cooper (2020). Nigeria Economic Alert: X-Raying the 2020 Federal Government of Nigeria Budget Proposal. Retrieved January 10, 2021, from www.pwc.com

Sachs, J. (1989). The Debt Overhang of Developing Countries. In G. Calvo, R. Findlay, P. Kouri and J. Macedo (Eds.), Debt, Stabilization and Development: Essays in Memory of Carlos Diaz Alejandro (pp. 80-102). Basic Blackwell.

Saifuddin, M. (2016). Public Debt and Economic Growth: Evidence from Bangladesh. Global Journal of Management and Business Research: Economics and Commerce, 16(5), 65-73.

Saungweme, T., \& Odhiambo, N. M. (2020). The Impact of Domestic and Foreign Public Debt on Economic Growth: Empirical Evidence from Zimbabwe. International Journal of Economics, 73(1), 77-106.

Todaro, P. M., \& Smith, S. C. (2006). Economic Development (9th ed.). Pearson Education.

Udoh, B. E., Ekeowa, L. K., Okechukwu, I. S., Obiora-Okafor, C. A., \& Nwonye, A. C. (2020). Effect of International Debt Burden on Economic Growth in Nigeria. Humanities and Social Sciences Letters, 8(2), 133-144. http://dx.doi.org/10.18488/journal.73.2020.82.133.144

Were, M. (2001). The Impact of External Debt on Economic Growth in Kenya: An Empirical Assessment. UNU-WIDER Research Paper, No. 116.

World Bank. (2020). International Debt Statistics. World Bank Debtor Reporting System; International Monetary Fund; and Bank for International Settlements.

World Bank. (n. d.). World Development Indicators. Retrieved from http://data.worldbank.org/datacatalog/world-development-indicators

Zaheer, S., Khaliq, F., \& Rafiq, M. (2019). Does Government Borrowing Crowd-Out Private Sector Credit in Pakistan. Journal of Finance \& Economics Research, 4(2), 30-41. https://doi.org/10.20547/jfer1904203

\section{AUTHORS' SHORT BIOGRAPHIES}

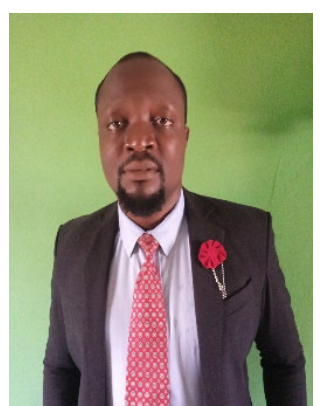

Mr. Kingsley Onyekachi Onyele is currently a $\mathrm{PhD}$ student at the Department of Banking and Finance, Michael Okpara University of Agriculture, Umudike, Nigeria. He received the B. sc. and M. sc. in Banking and Finance from Michael Okpara University of Agriculture, Umudike, Nigeria in 2012 and 2016, respectively. Mr. Kingsley Onyekachi Onyele is well experienced in data analysis, theoretical and practical aspects of banking and finance. He has published over twenty (20) academic articles in reputable journals. His research interests include, but not limited to international finance, econometrics, public finance, financial markets, corporate finance and agribusiness.

E-mail: onyele.kingsley@mouau.edu.ng, ORCID ID: https://orcid.org/0000-0002-4731-6139 


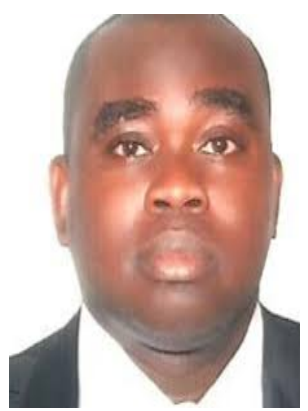

Mr. Emmanuel Chijioke Nwadike is a Lecturer at the Department of Financial Management Technology at the Federal University of Technology, Owerri, Imo State, Nigeria. He received his B. sc. and M. sc. in Agricultural Economics and Extension, and Financial Management Technology, respectively, from the Federal University of Technology, Owerri, Imo State, Nigeria. Mr. Emmanuel Nwadike is currently enrolled for the $\mathrm{PhD}$ programme in Banking and Finance at Michael Okpara University of Agriculture, Nigeria. He has many years of work experience in the banking industry. He has attended over 35 workshops, conferences and presentations. E-mail: chijioke.nwadike@,futo.edu.ng

ORCID ID: https://orcid.org/0000-0001-5177-0230 